\title{
Increasing knowledge: the grand challenge in marine biotechnology
}

\begin{abstract}
Antonio Trincone*
Istituto di Chimica Biomolecolare, Consiglio Nazionale delle Ricerche, Pozzuoli, Italy

${ }^{*}$ Correspondence: antonio.trincone@icb.cnr.it
\end{abstract}

Edited by:

Johannes F. Imhoff, Helmholtz Center for Ocean Research GEOMAR, Germany

Reviewed by:

Johannes F. Imhoff, Helmholtz Center for Ocean Research GEOMAR, Germany

Marcelino T. Suzuki, Laboratoire de Biodiversité et Biotechnologies Microbiennes, France

Keywords: marine biotechnology, natural products, metagenomics, bioprocesses, biodiversity

While contemplating the main challenges in the field of marine biotechnology, I found myself transported back to when I was a six years old boy, strolling along the beach with my grandfather and marveling at the diverse world of marine creatures which were washed up by the tide. My grandfather would point out their various shapes, how to best pick them up, their potential usefulness to us and whether or not they were edible.

This took place in the mid 1960's, not too long after marine biologist Dominick Mendola's own description of how he discovered the ocean through his own grandfather, who was a fisherman and first introduced him to the bounty of marine organisms. Mendola later worked in the field of marine biotechnology at the Scripps Institution of Oceanography in California, studying and growing marine organisms in order to harvest natural marine compounds and materials of interest for pharmaceutical, medical and industrial applications. His life was studied and reported by anthropologist Helmreich, whose simple definition of marine biotechnology as "a natural extension of cultural practices of garnering food from the ocean," beautifully summarizes the origins of this field and its deep significance to human society (Helmreich, 2003).

The grand challenge of the coming era is to continue to build our basic knowledge of marine environment-only through this understanding we can fully understand and make use of what marine organisms have to offer society in terms of new technology and applications. Indeed, we owe much of the commercial success of biotechnological developments and applications over the course of the second half of the Twentieth century to the basic knowledge and academic research findings garnered across a spectrum of scientific disciplines.

Casting a look to the future, it becomes apparent that the current overexploitation and anthropogenic impacts to the oceans represents a serious threat to further biotechnological advancements. Not only are the oceans the world's largest ecosystem, covering more than $70 \%$ of the earth's surface, but they also host the greatest diversity of life and contain a wealth of unexplored habitats and organisms meaning that they harbor a significant potential for biotechnological applications. Through a deep understanding of the complexity of the marine ecosystem we will be able to protect the ocean and the organisms that inhabit it.

Marine biotechnological advancements have already resulted in successes in the field of human health (i.e., marine drugs), fisheries (the development of molecular markers that help to avoid overfishing, etc.), and environmental recovery or restoration (i.e., marine organism based bioremediation). In a study, Leary et al. (2009) analyzed the number of patents on marine resources published between 1973 and 2007 and classified them in five application domains, including the food and cosmetics industries, agriculture, chemistry, and pharmacology. The number of patents in each of these fields increased over the studied time period with the latter two growing by 53.5 and $32.2 \%$, respectively (Trincone, 2012, 2013a). Many of advancements stemmed from basic research on ecological issues related to the chemical defense of prey, or on the growth-based selection of microbial communities in contaminated areas after petroleum pollution, etc. (e.g., Cafaro et al., 2013; Trincone, 2013b). Examples of applications resulting from biotechnological developments include the use of micro- and macroalgae for the production of biofuel and the development of small bioactive molecules to increase the sustainability of marine renewable energy resources. Marine polysaccharides are one of the most abundant renewable biomaterials found on land and in the oceans. In spite of this abundance the structure and functionality of rarer polysaccharides remain unknown and mostly unexplored. Brown seaweeds, for example, synthesize unique bioactive polysaccharides: laminarans, alginic acids, and fucoidans. A wide range of biological activities (anticoagulant, antitumor, antiviral, anti-inflammation, etc.) have been attributed to fucoidans (Silchenko et al., 2013) and their role with respect to structure-activity relationships is still under debate. A few available studies look at algal polysaccharide degradation in the context of biomass resource degradation/recycling, while in many Asian countries, where seaweed has a long usage history, direct macroalgae cultivation in the sea is actively being considered for the production of bioethanol (Gurvan and Czjzek, 2013). Regarding carbohydrate active enzymes, it must be said that these biocatalysts are described in different species from the marine environment. A recent renewed interest for the synthesis of small (poly)-glucosylated 
molecules and for the study of their actions has been derived from the literature (Trincone, 2011). In this context, extremozymes represent a very promising subject of great interest to both science and industry (Ojima, 2013; Trincone, 2013b). Compounds derived from marine algae, invertebrates, vertebrates, and microorganisms offer the potential to provide valuable nutraceuticals and functional food ingredients, potentially meeting the requirements for bioactive substances by future consumers (Kim, 2013).

Examples of marine basic principles and complexity that can be tapped and studied with a final marine biotechnology optic range from symbiotic relationships, to the biology and chemistry of defense mechanisms, to the chemo-ecology of marine invasions, to the strategies found in prokaryotes to adapt to extreme environments (Trincone, 2011). The adaptation of marine organisms to a wide range of environmental conditions (temperature, salinity, tides, pressure, radiation, light) render them an enormous reservoir of interesting biological material for both basic research and biotechnological improvements (Trincone, 2011). The last years have clearly shown that genome studies and new molecular techniques are useful tools to study marine life, such as symbiosis and its molecular aspects (Muller et al., 2004); biodiversity (Muller et al., 2003); and defense mechanisms (Thakur et al., 2005). Gathering the wealth of knowledge already existing with an interdisciplinary approach already enables the identification an arsenal of enzymes and pathways greatly in demand for biotechnological applications.

To nurture and develop the continuation of these recent success stories, appropriate infrastructures combined with new technologies will be needed. Partnerships between marine scientists working in academia and private industry, for example, will allow a rapid transfer of research findings in marine science to commercial use. If industrial chemists and engineers work together with marine molecular biologists, exciting new frontiers will successfully emerge over the course of the next decades, especially if the scale of action transcends political boundaries (Thakur et al., 2008; Wijffels, 2008; Coté, 2011; Trincone, 2013b).
The high chemical diversity found in marine natural products has the ability to further drive developments and market growth, a rewarding prospect for the future (Grabowski et al., 2008). The great natural biodiversity of marine bacteria and fungi, for example, can serve as new sources for marine natural products using new technologies in analytical spectroscopy and can give a boost to the excitement and anticipation of new marine drug discoveries (Imhoff et al., 2011). Marine -omics, from metagenomic technologies, which currently offer new and promising strategies for marine biodiscovery, to metabolomics for bio-function exploration, will also be developed in the future, enabling new approaches for the study of chemically mediated interactions. Monitoring metabolites through Mass Spectrometry, Nuclear Magnetic Resonance Spectroscopy, fluxomics and MS-imaging will be of great help in the localization and quantification in cells and tissues (Goulitquer et al., 2012).

Another sign of the growing importance of marine biotechnological developments is represented in the publication of the Position Paper 20 by the European Marine Board (2013), entitled "Navigating the Future IV." The report recognizes that marine science research will be highly relevant to societal challenges, as listed in the EU Framework Programme Horizon 2020; indeed most of the document is organized around these lines. Several emerging technologies are outlined, including (i) robotics, (ii) miniaturized solutions for marine monitoring, (iii) biomimetics, (iv) acoustics, (v) nanobiotechnlogy, (vi) renewable energy harvesting (wave energy, algae biofuels), and (vii) high performance computing. The authors point out that while a lot of progress has been made to advance the field, many challenges remain, including the deep comprehension of the "marine biotechnology landscape" and a multidisciplinary approach to education and training. In order to increase our knowledge on these emerging technologies, a strong investment in fundamental research is of paramount importance.

Recently the Global Strategic Business Report (GSBR) was published analyzing the worldwide market for marine biotechnology products (GSBR Marine Biotechnology, 2013). It focused on both product segments, such as marine biomaterials, marine bioactive substances and others, and on applications outlined as (i) industrial products, (ii) healthcare biotechnology, (iii) consumer products etc. This report gathering important information about the competitive landscape for marine-based products indicates a bright future despite the economic slowdown due to the recent global crisis and the marine biotechnology global market is forecasted to undergo substantial growth in the years to come.

This commentary started off with an autobiographical anecdote and continued through different scientific aspects all the way to market economics related to modern marine biotechnology. At the end of this article the somewhat overused rainbow of biotechnology can be recalled. It is currently composed by at least $10 \mathrm{col}-$ ors (blue for marine biotechnology obviously). This is an unequivocal proof of the complexity of the interdisciplinary network discussed above. In conclusion one might just flip the title around: the great challenge for marine biotechnology is to foster knowledge.

\section{ACKNOWLEDGMENTS}

The organization of CNR bibliographic facilities in supporting this contribution is acknowledged.

\section{REFERENCES}

Cafaro, V., Izzo, V., Notomista, E., di Donato, A., Marine hydrocarbonoclastic bacteria. (2013). "Polysaccharide-degrading enzymes from marine bacteria," in Marine Enzymes for Biocatalysis ed A. Trincone (Cambridge: Woodhead Publishing), 429-453.

Coté, I. M. (2011). Conservation biology: the many ways to protect biodiversity. Curr. Biol. 21, R468-R470. doi: 10.1016/j.cub.2011.05.023

European Marine Board. (2013). Navigating the Future IV. Position Paper 20. Ostend: European Marine Board.

Goulitquer, S., Potin, P., and Tonon, T. (2012). Mass spectrometry-based metabolomics to elucidate functions in marine organisms and ecosystems. Mar. Drugs 10, 849-880. doi: 10.3390/md10040849

Grabowski, K., Baringhaus, K.-H., and Schneider, G. (2008). Scaffold diversity of natural products: inspiration for combinatorial library design. Nat. Prod. Rep. 25, 892-904. doi: 10.1039/b715668p

Gurvan, M., and Czjzek, M. (2013)."Polysaccharidedegrading enzymes from marine bacteria," in Marine Enzymes for Biocatalysis, ed A. Trincone (Cambridge: Woodhead Publishing), 429-453.

Helmreich, S. (2003). A tale of three seas: from fishing through aquaculture to marine biotechnology 
in the life history narrative of a marine biologist. Maritime Stud. 2, 73-94.

Imhoff, J. F., Labes, A., and Wiese, J. (2011). Bio-mining the microbial treasures of the ocean: new natural products. Biotechnol. Adv. 29, 468-482. doi: 10.1016/j.biotechadv.2011. 03.001

Kim, S.-K. (2013). Marine Nutraceuticals: Prospects and Perspectives. Boca Raton, FL: CRC Press.

Leary, D., Vierros, M., Hamon, G., Arico, S., and Monagle, C. (2009). Marine genetic resources: a review of scientific and commercial interest. Mar. Policy 33, 183-194. doi: 10.1016/j.marpol.2008. 05.010

Marine Biotechnology—Global Strategic Business Report. (2013). Available online at: http:// www.researchandmarkets.com/reports/595580/

Muller, W. E., Brummer, F., Batel, R., Muller, I. M., and Schroder, H. C. (2003). Molecular biodiversity. Case study: Porifera (sponges). Naturwissenschaften 90, 103-120. doi: 10.1007/ s00114-003-0407-6

Muller, W. E., Grebejuk, V. A., Thakur, N. L., Thakur, A. N., Batel, R., Krasko, A., et al. (2004). Oxygen-controlled bacterial growth in the sponge Suberitesdomuncula: toward a molecular understanding of the symbiotic relationship between sponge and bacteria. Appl. Environ. Microbiol. 70, 2332-2341. doi: 10.1128/AEM.70.4. 2332-2341.2004
Ojima, T. (2013). "Polysaccharide-degrading enzymes from herbivorous marine invertebrates," in Marine Enzymes for Biocatalysis, ed A. Trincone (Cambridge: Woodhead Publishing), 429-453.

Silchenko, A. S., Kusaykin, M. I., Kurilenko, V. V., Zakharenko, A. M., Isakov, V. M., Zaporozhets, T. S., et al. (2013). Hydrolysis of fucoidan by fucoidanase isolated from the marine bacterium, formosa algae. Mar. Drugs 11, 2413-2430. doi: $10.3390 / \mathrm{md} 11072413$

Thakur, N. L., Jain, R., Natalio, F., Hamer, B., Thakur, A. N., and Muller, W. E. G. (2008). Marine molecular biology: an emerging field of biological sciences. Biotechnol. Adv. 26, 233-245. doi: 10.1016/j.biotechadv.2008.01.001

Thakur, N. L., Peroviæ-Ottstadt, S., Batel, R., Korzhev, M., Diehl-Seifert, B., Müller, I. M., et al. (2005). Innate immune defense of the sponge Suberitesdomuncula against gram-positive bacteria: induction of lysozyme and AdaPTin. Mar. Biol. 146, 271-282. doi: 10.1007/s00227-0041438-z

Trincone, A. (2011). Marine biocatalysts: enzymatic features and applications. Mar. Drugs 9, 478-499. doi: $10.3390 / \mathrm{md} 9040478$

Trincone, A. (2012). Some enzymes in marine environment: prospective applications found inpatent literature. Recent Pat. Biotechnol. 6, 134-148. doi: $10.2174 / 187220812801784696$
Trincone, A. (2013a). Biocatalytic processes using marine biocatalysts: ten cases in point. Curr. Org. Chem. 17, 1058-1066.

Trincone, A. (ed.). (2013b). "Marine enzymes for biocatalysis: sources, biocatalytic characteristics and bioprocesses of marine enzymes," in Biomedicine (Cambridge: Woodhead Publishing), Series No. 38. Available online at: http://www.woodhead publishing.com/en/book.aspx?bookID $=2822$

Wijffels, R. H. (2008). Potential of sponges and microalagae for marine biotechnology. Trends Biotechnol. 26, 26-31. doi: 10.1016/j.tibtech.2007. 10.002

Received: 23 January 2014; accepted: 07 February 2014; published online: 25 February 2014.

Citation: Trincone A (2014) Increasing knowledge: the grand challenge in marine biotechnology. Front. Mar. Sci. 1:2. doi: 10.3389/fmars.2014.00002

This article was submitted to Marine Biotechnology, a section of the journal Frontiers in Marine Science.

Copyright (c) 2014 Trincone. This is an open-access article distributed under the terms of the Creative Commons Attribution License (CC BY). The use, distribution or reproduction in other forums is permitted, provided the original author(s) or licensor are credited and that the original publication in this journal is cited, in accordance with accepted academic practice. No use, distribution or reproduction is permitted which does not comply with these terms. 